\title{
Kertovan muutosselonteon menetelmä
}

\author{
Matti Laitinen
}

\author{
Suuri osa organisaatioiden kehittämistä käsittelevistä \\ tutkimuksista on luonteeltaan ns. tapaustutkimuksia. \\ Lukijan kannalta nämä tutkimukset voivat olla \\ ongelmallisia, mikäli muutosta kuvaavaa kertomusta eli \\ muutosnarratiivia ei ole sisällytetty tutkimusraporttiin. \\ Tällöin hänelle esitetään vain tilanne ennen \\ interventiota ja tilanne intervention jälkeen, mutta ei \\ kerrota, millä tavalla muutosprosessi eteni.
}

Käyttäytymis- ja sosiaalitieteissä narratiivista lähestymistapaa on sovellettu runsaasti viime vuosina. Kerronnallisuus on tällöin määritelty hyvin vaihtelevasti. Usein kertomus on määritelty ajallisesti eteneväksi enemmän tai vähemmän juonelliseksi kokonaisuudeksi, jolla on alku, keskiosa ja loppu (Czarniewska 1998). Toisaalta kertomukset on myös voitu nähdä laajemmin asioita yhteenliittävinä sidoksina, joilta ei ole edellytetty tunnistettavaa, eksplisiittistä rakennetta. (Mishler 1995, kts myös Valkonen 1997).

Organisaatioita käsittelevässä tutkimuksessa narratiivinen lähestymistapa on tarkoittanut lähinnä kolmea asiaa (Czarniewska-Joerges 1995): tutkimusten kirjoittamista kertomusten muotoon, kertomusten keräämistä kentältä tutkimusaineistoksi ja organisaation elämän ymmärtämistä kertomuksen luomisena.

Tässä artikkelissa organisatorinen muutosnarratiivi tarkoittaa kertomusta siitä, mitä organisaa- tio on käynyt läpi esimerkiksi jonkin tietyn kehittämisprojektin kuluessa. Se ei kerro ainoastaan tapahtumien etenemisestä, vaan sen pitäisi sisältää myös jokin selonteko, kuinka organisaatiossa työskentelevät ihmiset ovat konstruoineet oman historiansa ja mitä he ovat oppineet aiemmista kokemuksistaan. (Laitinen 1998.)

Miksi tällaisia muutosnarratiiveja tarvitaan? Ensinnäkin siksi, että on epärealistista olettaa organisatoristen muutosprosessien etenevän kurinalaisesti suunnitelmien mukaan. Inhimilliset järjestelmät toimivat ja kehittyvät harvoin täysin rationaalisesti ja lineaarisesti (Gustavsen ym. 1991 ja 1996, Senge 1990, Tosey ja Nicholls 1999). Esimerkiksi Marris (1974) on todennut että "kaikki todelliset muutokset sisältävät menetyksiä, pelkoa ja kamppailua“. Toisin sanoen, jos muutosprosessia ei kuvata, menetetään tärkeää informaatiota ja mahdollisuuksia oppia tapahtuneesta. Tämä saattaa myös osaltaan selittää sitä tosiasiaa, että uusissa kehittämishankkeissa tör- 
mätään yhä uudelleen samoihin vastoinkäymisiin (esim. johdon tuen puute) ilman, että aiemmista hankkeista saaduista kokemuksista pystyttäisiin ottamaan oppia.

Myös muutokselle annettuja merkityksiä on vaikea ymmärtää, mikäli uuteen toimintatapaan johtanutta prosessia ei tunneta. Organisaatiomuutokset saattavat yhtäältä sisältää tuskallisia tai epäoikeudenmukaisiksi koettuja episodeja, jotka vaikuttavat myöhemmin kielteisesti henkilöiden tapaan arvioida toimeenpantuja uudistuksia (Harrison 1995a, Noer 1993, Sulander 1992). Toisaalta osallistavat ja oikeudenmukaisiksi koetut prosessit voivat tuottaa sitoutumista ja johtaa jopa siihen, että (ulkopuolisen tutkijan silmin) pääsääntöisesti kielteisiä elementtejä sisältäviä muutoksia arvioidaan kuitenkin myönteisesti.

\section{Kertovan mutosselonteon menetelmän tausta}

Kertovan muutosselonteon menetelmä perustuu Harrén ja Secordin (1972), myöhemmin erityisesti Harrén ym. (1979, 1985, 1994), kehittämään selontekojen menetelmään ${ }^{1}$. Lisäksi sovelletaan historian tutkimuksen (Thompson 1988 ja Yow 1994), elokuvakerronnan (Arijon 1976) ja etnografian (Eräsaari 1995, Hammersley 1992, Pratt 1986) lähestymistapoja (Kuva 1).

Selontekojen menetelmän taustalla on etogeni-

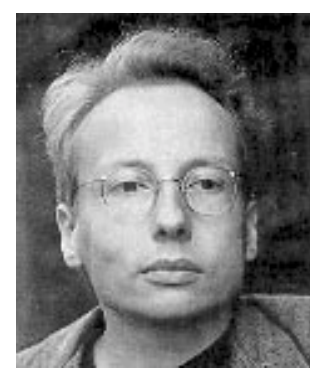

Matti Laitinen

aksi kutsuttu omaperäinen sosiaalipsykologinen suuntaus. Etogenian synty ajoittuu vuoteen 1972, jolloin Harré ja Secord julkaisivat teoksen The Explanation of Social Behaviour, josta tuli uuden koulukunnan ohjelmanjulistus. Teos liittyi 1970-luvun sosiaalipsykologian kriisikeskusteluun, joka tiivistyi pitkälti kysymykseen laboratoriokokeen asemasta: sosiaalipsykologinen tutkimushan oli ollut valtaosaltaan laboratoriokokeiden tekemistä (Myllyniemi 1998, Uotila ja Ylijoki 1984). Harré ja Secord (1972) kritisoivat julistuksessaan tällaista modernin luonnontieteen kaltaista eksaktisuutta ihanteena pitävää tiedekäsitystä ja sen mekanistista ihmiskuvaa.

Harrén ja Secordin (1972) mukaan ihmisen sosiaalinen toiminta on aina merkitysten läpäisemää. Samalla ihminen on oma-aloitteinen ja itseohjautuva, mikä tekee mahdolliseksi toiminnan säätelyn. Tietoisen yksilön vapaudella on tosin rajansa: etogeniassa ollaan kiinnostuneita

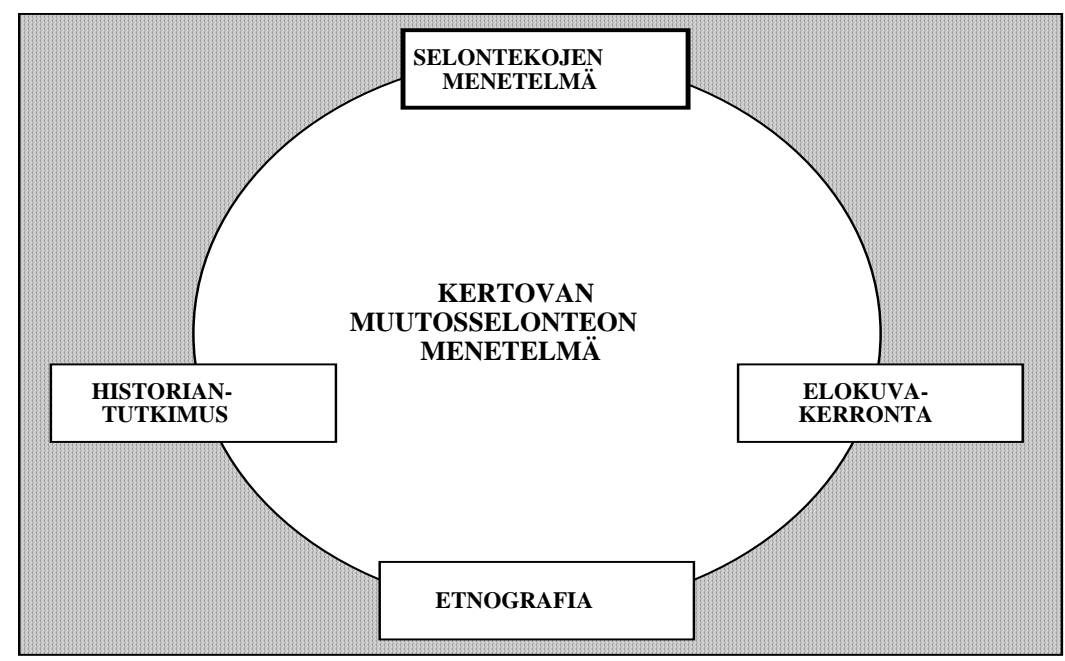

KUVA 1.

Kertovan muutosselonteon menetelmän lähtökohdat. 
erityisesti siitä, kuinka sosiaalinen järjestelmä ohjaa ihmisen toimintaa (Myllyniemi 1998).

Selontekojen menetelmän keskeiset käsitteet ovat episodi, selonteko ja neuvottelu. Harré ja Secord (1972) määrittelevät episodin kahdella tavalla. Ensinnäkin episodi on mikä tahansa sosiaalisen elämän luonnollinen katkelma. Toiseksi episodi on mikä tahansa jakso tapahtumia, joihin ihmiset sitoutuvat ja jotka muodostavat jonkinlaisen kokonaisuuden.

Episodeja voivat olla esimerkiksi juhla-ateria, luento, suklaan ostaminen, naimisiin meneminen ja eroaminen (Harré 1974). Esimerkkien monimuotoisuus paljastaa, että episodi voi kattaa yhtä hyvin jonkin yksittäisen ja satunnaisen tapahtuman kuin vaikkapa ihmisen koko elämän tai ryhmän vaiheet perustamisesta hajoamiseen. Lisäksi episodien merkitykset toimijoille itselleen, muille ihmisille ja koko yhteiskunnalle voivat vaihdella suuresti - eroa on esimerkiksi suklaan ostamisella ja lakolla. (Uotila ja Ylijoki 1984.)

Ihmisten omasta toiminnastaan antamia selityksiä kutsutaan selonteoiksi. Niissä ihmiset tekevät oman toimintansa ymmärrettäväksi ja perustelevat tekojaan. (Marsh ym.1978 ja Myllyniemi 1998.) Selontekojen keräämisen jälkeen tutkijan on analysoitava selonteot. Selontekojen analyysissä tutkija pyrkii löytämään selonteoista ristiriitaisuuksia, epäjohdonmukaisuuksia, puolustusmekanismeja yms. Samalla tutkijan tehtävänä on päästä sisälle tutkittavien maailmaan, näkemään asioita näiden silmillä ja tavoittamaan niitä merkityksiä, joita nämä toiminnalleen antavat. (Harré ja Secord 1972, Marsh ym. 1978, Uotila ja Ylijoki 1984.)

Selontekojen analyysin jälkeen tuloksista on neuvoteltava tutkittavien kanssa. Keskustelussa tut-

Taulukko 1. Muutoskertomuksen tuottamisen vaiheet.

VAIHE

Avauskertomuksen kirjoittaminen

Tutkimuksen kontekstin kuvaaminen

Episodisen etenemiskuvauksen laatiminen

Selontekojen kerääminen

Muutoskertomuksen kirjoittaminen

Muutoskertomuksesta neuvotteleminen

\section{VAIHEENSISÄLTÖ}

kuvataan tutkijan sisäänpääsy kentälle

kuvataan muutoksen tapahtumapaikka

1. kerätään tarkasteltavaan muutosprosessiin liittyvää aineistoa

2. aineistosta poimitaan episodeja

3. episodit listataan kronologisessa järjestyksessä

1. valitaan avainepisodit

2. kerätään episodeihin osallistuneilta henkilöiltä selontekoja tapahtuneesta

episodista etenemiskuvausta korjataan ja täydennetään selonteoista saadulla aineistolla

1. muutokseen osallistuneet henkilöt lukevat kertomuksen

2. keskustellaan siitä, miten muutoskertomus saataisiin mahdollisimman hyvin vastaamaan tapahtunutta 
kija pyrkii tarkistamaan omia selontekojaan ja testaamaan omien tulkintojensa pätevyyttä. Neuvottelun kuluessa voidaan keskustella eri vaihtoehdoista ja pyrkiä ratkaisemaan, mitä selontekoa jostain episodista olisi pidettävä toistaiseksi oikeana. On myös mahdollista, että neuvottelun tulokset jäävät monitulkintaisiksi tai epäselviksi. (Harré ja Secord 1972, Uotila ja Ylijoki 1984.)

\section{Kertovan muutosselonteon m e net e l m ä}

Muutosnarratiivin tuottaminen jakautuu kuuteen vaiheeseen: avauskertomuksen kirjoittaminen, tutkimuksen kontekstin kuvaaminen, episodisen etenemiskuvauksen laatiminen, selontekojen kerääminen, muutoskertomuksen kirjoittaminen ja muutoskertomuksesta neuvotteleminen (Taulukko 1).

Muutosprosessin kuvaus aloitetaan etnografiasta lainatulla avauskertomuksella. Eräsaari (1995) on kuvannut avauskertomusta siksi tutkimuksen osaksi, jota ei ole tarvinnut "tappaa tieteellä". Avauskertomus on nimensä mukaisesti kertomus, joka kuvaa tutkijan sisäänpääsyä kentälle. Näissä kertomuksissa tutkijan läsnäolo persoonana on sallittu, kenties sitä on jopa vaadittu tai odotettu. (Eräsaari 1995, Pratt 1986.)

Avauskertomuksessa voidaan myös kuvata sitä roolia, jossa tutkija saapuu tutkittavien luo. Klassisissa etnografioissa tällaisia rooleja ovat esimerkiksi haaksirikkoisen, valloittajan ja tiedemiehen roolit. Byrokratioita tutkiessaan Eräsaari (1995) kertoo avauskertomuksessaan esiintyneensä hyvin erilaisissa rooleissa: sankarina, auttajana, narrina, konnana ja jopa objektivoijan sekä imperialistin roolissa.

Avauskertomuksen jälkeen kuvataan tutkimuksen konteksti. Selontekojen menetelmää hyödyntäneissä tutkimuksissa on lähinnä kuvattu se tapahtumapaikka, kuten koulu, jalkapallostadionin katsomo tai sairaala, johon tutkimus välittömästi sijoittuu (kts. esim. Hakanen 1991, Heikkinen 1988 ja Marsh ym. 1978). Tämä on kuitenkin usein riittämätöntä. Hyvä esimerkki laa- jemmasta kontekstin kuvauksesta löytyy esimerkiksi Forssén-Nybergiltä (1995). Toimistotyön kehittämishanketta käsittelevässä tutkimuksessaan hän on kuvannut myös organisaation toimintaympäristön muuttumista (asiakkaat, kilpailutilanne, lakimuutokset, työmarkkinatilanne, lama, työttömyys).

Ensimmäisenä vaiheena varsinaisen muutosprosessin kuvauksen laatimisessa on tuottaa episodinen etenemiskuvaus tapahtuvista - tai jo tapahtuneista - muutoksista. Tämä tapahtuu kahdessa vaiheessa: ensiksi kerätään tarkasteltavaan muutosprosessiin liittyvää aineistoa, minkä jälkeen aineistosta poimitaan episodeja, jotka listataan peräkkäin kronologisessa järjestyksessä. Elokuvan käsikirjoituksessa tätä vaihetta kutsuttaisiin “master storyksi“ (Arijon 1976).

Episodisen etenemiskuvauksen ei vielä tarvitse sisältää tarkkoja yksityiskohtia tapahtuneesta kyseessä on ainoastaan tulevan muutoskertomuksen ensimmäinen listaus, joka voidaan toteuttaa esimerkiksi aikajanan muodossa. Ratkaisua on hyödynnetty selonteon menetelmään perustuvissa tutkimuksissa aiemminkin. Esimerkiksi Marshin ym. (1978) jalkapallokatsomoiden väkivaltaa käsittelevässä tutkimuksessa kuvattiin aikajanan avulla tapahtumien kulkua koti- ja vierasotteluissa.

Aineiston keräämisen menetelmät riippuvat luonnollisesti tutkimuksen luonteesta. Jos kyseessä on toimintatutkimus tai tutkija on osallistuvana havainnoijana seuraamassa tapahtuvaa muutosta, mahdollisuudet ja keinot aineiston keräämiseen ovat toiset kuin silloin, jos yritetään myöhemmin rekonstruoida tapahtumia. Edellä mainitussa tapauksessa tutkija voi tehdä esimerkiksi kenttämuistiinpanoja, reaaliaikaisia haastatteluja sekä käyttää nauhuria ja videokameraa. Sen sijaan jälkikäteen muutoksia tarkasteltaessa selontekojen keräämistä valmisteleva vaihe jää pitkälti erilaisten muutoksesta kertovien dokumenttien ja avainhenkilöiden haastattelujen varaan.

Episodisen etenemiskuvauksen valmistuttua, kerätään episodeihin osallistuneilta henkilöiltä selontekoja tapahtuneesta. Selontekojen kerää- 
minen toteutetaan käytännössä niin, että episodisesta etenemiskuvauksesta valitaan avainepisodit, joihin sitten "zoomataan" yksilö- tai ryhmähaastatteluin (Arijon 1976). Tavoitteena on, paitsi saada lisäaineistoa tapahtumien kulusta, myös kuva siitä, miltä muutokset ja niiden vaikutukset ovat näyttäneet eri toimijoiden silmin.

Muutoskertomusta kirjoitettaessa käytetään pohjatekstinä jo aiemmin tuotettua episodista etenemiskuvausta, jota korjataan ja täydennetään erityisesti selonteoista saadulla aineistolla. Kyseessä on samalla yksi aineiston analysoinnin keskeisimmistä vaiheista - selontekoja, havaintoja, dokumentteja yms. aineistoa käsitellään rinnakkain ja niiden pohjalta yritetään luoda kertomus, joka mahdollisimman hyvin kuvaisi muutoksen tapahtumista ja toisi esiin, miltä muutokset ja niiden vaikutukset ovat näyttäneet eri osallistujien silmin. Tämän vaiheen työskentely muistuttaa historioitsijan työskentelyä perustuen eri tietolähteiden antaman tiedon kriittiselle yhdistelylle ja arvioinnille luotettavan historiallisen kuvauksen aikaansaamiseksi ${ }^{2}$. Erityisesti mikrohistorian (Thompson 1988) ja oraalihistorian (Yow 1994) näkökulmista metodeissa on paljon yhtäläisyyttä.

Muutoskertomuksesta neuvotteleminen tarkoittaa minimissään sitä, että tutkijan kirjoittama muutoskertomus annetaan muutokseen osallistuneiden henkilöiden luettavaksi ja kommentoitavaksi, minkä jälkeen siitä käydään yhteinen keskustelu. Tavoitteena on saada muutoskertomus vastaamaan, paitsi tapahtunutta, myös tutkimushenkilöiden kuvaa tapahtuneesta mahdollisimman hyvin.

\section{Menetelmän soveltaminen organisatorisen mutos- prosessin kuvaukeen}

Tämän luvun tarkoituksena on havainnollistaa menetelmän avulla tuotettavaa muutosnarratiivia. Seuraavaksi esitettävät näytteet on poimittu muutosnarratiivista, joka kuvasi yhden teollisuusyrityksen kokoonpano-osastolla tapahtunutta kehittämishanketta ja sen myötä tapahtunutta siirtymistä itseohjautuvaan ryhmätyöhön (Laitinen 1998).

Avauskertomusta havainnollistava näyte sisältää kolme ensimmäistä kappaletta muutoskertomuksen alusta. Niissä kuvataan, kuinka toimintatutkimuksellinen yhteistyö tutkijoiden ja yrityksen edustajien välillä lähti liikkeelle, mikä oli kertojan rooli kehittämistyön alkaessa sekä keitä kaikkia oli mukana projektia käynnistettäessä ja mikä oli kenenkin rooli. Lisäksi luodaan kuvaa niistä haasteista, joihin kehittämishankkeen käynnistämisellä pyrittiin vastaamaan.

Kunlin Yritys Oy:stäensimmäisenkerranhelmikuussa 1992työskennellessänitutkimusapulaisenaTeknillisen korkeakoulunTyöpsykologianlaboratorionryhmiätutkivassatutkimusryhmässä,johonkanuilisäksenikaksi kokemuttatutkijaajatutkimusapulainen. Eräänäaamuna toinen tutkijoista kertoi, että Yritys Oy:stä oli otettuyhteyttäjaehdotettukeskusteluaryhmienkehittämiseenliittyen.

Kehittämisprojektinalkukeskustelupidettiin6maaliskuuta 1992 Teknillisenkorkeakoulun Työpsykologian laboratoriossa. Paikallaolikokotutkimusryhmäjakaksi tuotantopäälikköäYritysOy:stä. Tilaisunden aluksituotantopäällikötkertoivat Yritys Oy:stäjajohtamistaan yksiköistä. Hekuvasivat, kuinka Yritys Oy:ssäolisïrryttytulosjohtamiseen. Operatiivinentoimintaoliorganisoitu tulosyksiköiksi, joitamyynti-, markkinointi-, tuotekehitysyksiköidenjamuidennïnsanottujentukitoimintojentulipalvella. Uudistuksellapyrittiin aikaisempaatuloksellisempaanjajoustavampaantyötopaan. Tavoitteenaoliasiakkaidenpalvelulleperustuvatuotanto-organisaatio,jossavaltajavastunolisivatsiellä, missätoimintatapahtuu. Yrityksessäpuhuttiinperinteisen “organisaatiopyramidinkeikauttamisestaylösalaisin”.

Lähtötilannetuntuimonellatapaaepävarmalta. Johto oli ilmaissut, mihinsunntaantoimintaatulisi kehittää, muttatulosyksiköt eivät olleetlöytäneet konkreettisia keinojatoimintansakehittämiseen. Tulosyksiköidenasemaeiollutvieläselkeytynytjaneolivatvastaetsimässä unttatapaatoimia. Epävarmunttalisäsi, ettäsamanaikaisestitulosjohtamiseensiirtymisen kanssa Yritys $O y: n$ Ernestintehdas olilopetettujasentoimintojasiirrettiin Hemminkïn. Irtisanomistenmyötätoistasataahenkilöä olimenettänyttyöpaikkansa. Lisäksiedellisenävrotena 
olitehtynelipäiväistätyöviikkoa. Erityisestitoimihenkilöttunsivat asemansauhatuiksi. Toisaaltatulosyksiköt vaikuttivatkaïnostoviltakehittämistäjatutkimustaajatellen: tuotantopäällikötolivat innostuneita yhteistyöstä jayksikötnäyttivättarjoavanmahdollisunksiatyöryhmientutkivaan kehittämiseen. Keskusteluapäätettiin jatkaajasovittiinseuraavastatopaamisestaYritys $O y: n$ tehtaallaHemmingissämaalisknunlopulla.

Seuraava näyte muodostuu kolmesta ensimmäisestä muutoskertomuksen kontekstia kuvanneesta kappaleesta. Näytteessä esitellään lyhyesti valmistettava tuote, fyysinen ympäristö ja työn tekijät.

Tulasyksikkövïdenkokoonpanossavalmistettiinerilaisia sähköteknillisiäsäätölaitteita. Säätölaitteetolitarkoitettu erityisestitoimisto-jaliikerakenmuksïnkutenmyymälöihin, hotelleihinjaravintoloihin. Tuotevalikoima olimuuttumassaniin, ettäosastonpäätuotteeksiolinousemassaunsikehittyväsäätölaiteperhenimeltäänSampa

Fyyxisenätilanakokoonpano-asastoolitavanomainentehdassali: kokoonpanopöytiäsuorissariveissä, parisunrta oviaukkoasalinvastakkaisissapäissäjakäytövätosien javalmiidentuotteidenkuljettamistavarten. Salinyhdessäkulmassaolityönjohtokoppi,jokaolijaettukahteenhuoneeseen,joistaensimmäisessätyöskentelivättyönjohtajajatuotannonsunnnittelïajajälkimmäisessätuotantopäällikkö. Tulosyksikönkaksimuutavalmistusosastoa elipintakäsittely (pesujamaalaus) jakoneistus sijaitsivatviereisissäsaleissa (kuva2).
Kokoonpanossatyöskenteli 11 henkilöä. Kutenkevyessä kokoonpanossauseinkaikkihenkilötolivatnaisia. Ikäjakaumavaihteli 30 ja 60vuodenvälillä keski-iän ollessa 45 vuotta. Tässäsuhteessaosasto eiollutmitenkäänpoikkeuksellinen, sillävähänylinelikymppisetolivat muutenkintehtaanyleisinikäryhmä. Kansakouluoli tyypillisinkoulutustausta, yhdelläolikeskikoulujayhdelläammatillinenperustutkintoerialaltakuinmetalli-taisähkötekniikasta. Kukaaneiollutvarsinaisesti sunnnitellutryhtyvänsäteollisunstyöntekijäksi, vaanpikemminkin ammattiinolipäädyttyerilaistensattumustenkautta. Tästähuolimattatyöhönolijäätyjauseimmillaoli 10-20vuodentyökokemus Yritys Oy:ssä. Osa olitehnytkokotyöuransasamantyönantajanpalveluksessa

Kokoonpanon muutosprosessi kesti lähes kolme vuotta ja koostui kolmesta päävaiheesta: nykytilan analysoinnin vaiheesta, visiolähtöisen kehittämisen vaiheesta ja yksittäisten interventioiden vaiheesta. Seuraava näyte sisältää sekä nykytilan analysoinnin vaiheen ennakkojäsentäjänä käytetyn episodisen etenemiskuvauksen että palaverikäytännön käynnistymistä kuvaavat muutoskertomuksen kappaleet.

Viikko-ja kuukausipalaverit alkavat. Samanaikaisestikehittämisprojektin alkukeskustelujen (vertaaavauskertomus) kanssakäynnistyivättulosyksikkövïdessä kunkausi-javiikkopaloverit. Kunkausipalaverientarkoituksenaoliantaayksiköntyöntekijöilletietoajapalautettayksiköntaloudellisestakehityksestä. Kuukausipalavereihinsuhtauduttïnnïden alkamisestalähtien

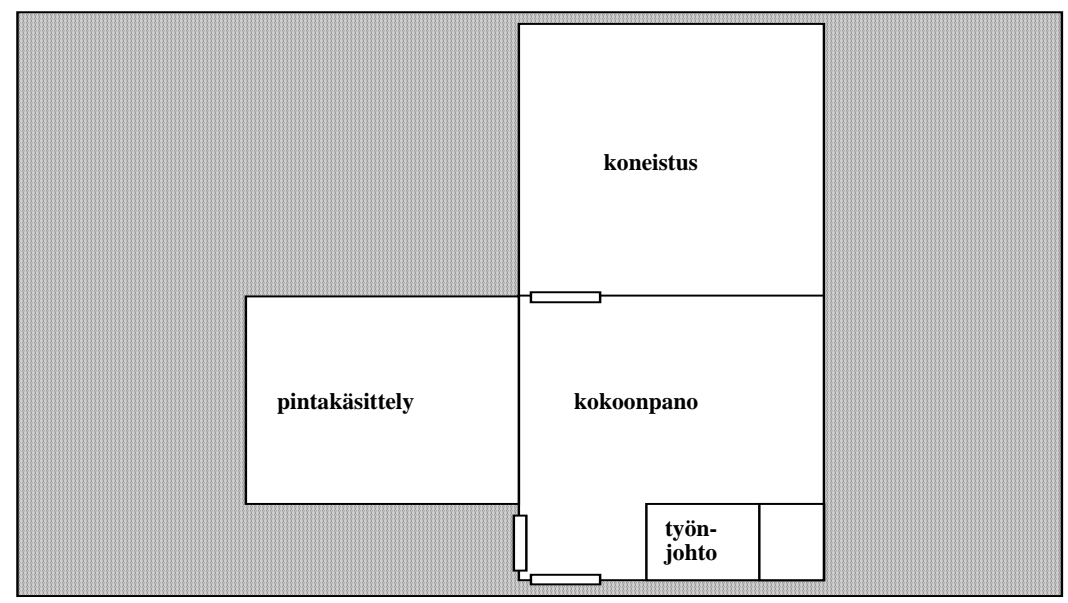

KUVA 2. Tulosyksikkö viiden pohjapiirros 
KUVA 3 Kehittämisprojektissa tehdyt toimenpiteet ja tulosyksikkö viiden kokoonpanossa tapahtuneet muutokset nykytilan analysoinnin vaiheen aikana.

\section{KEHITTÄMISPROJEKTISSA TEHDYT TOIMENPITEET}

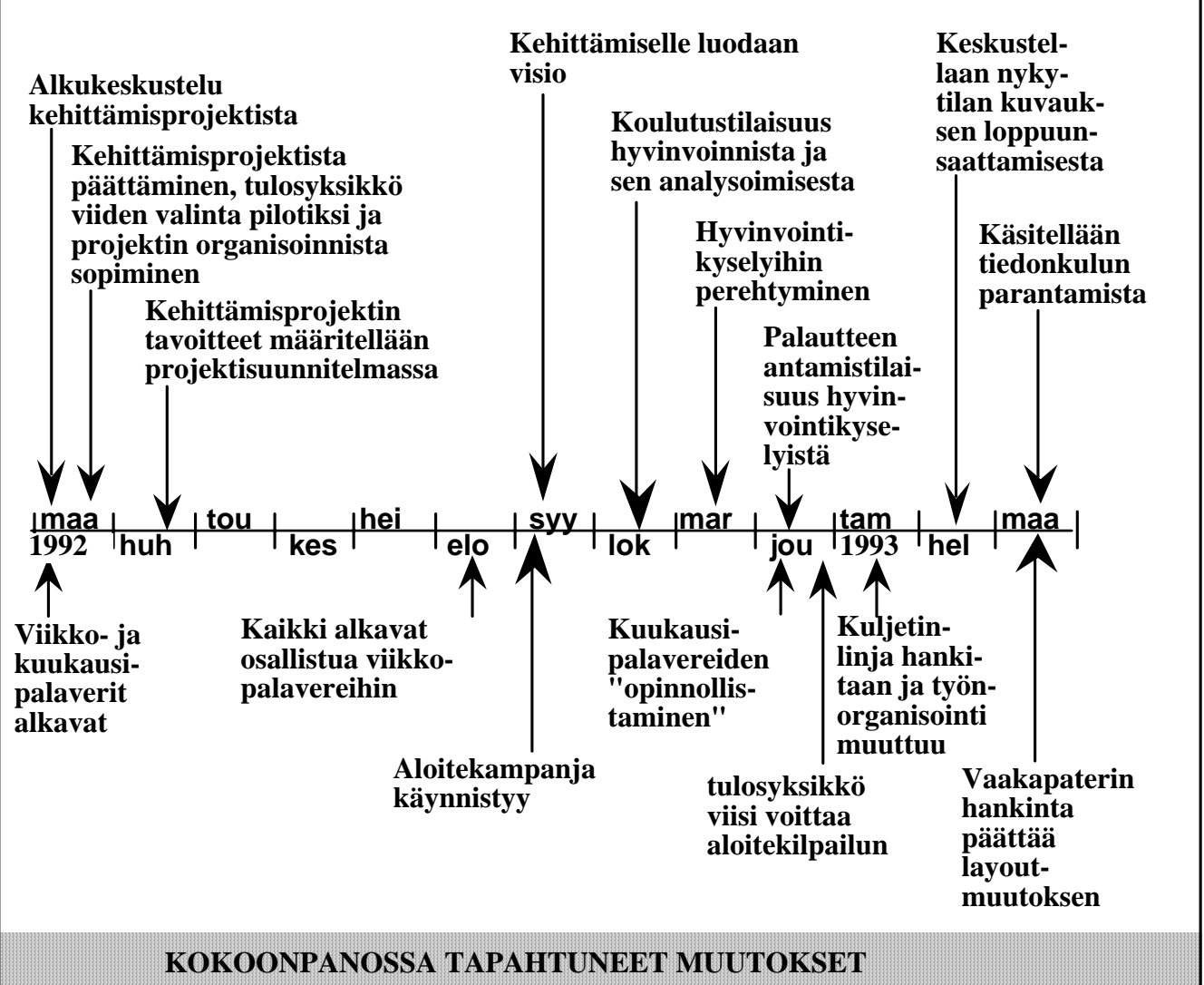

ti. Ernestintehdas olilopetettu, toimitusjohtajavaihtui, erilaisiahuhujaliikkuijatulevaisundestaoltïnhuolestuneitajotenoltïn "enemmänkuinkïnnostuneita"sïtämitenyrityksellämeni.

VükkopalavereitakutsuttiinaluksiTUTU-palavereiksi (TullaanTutuksi).Nïdentovoitteenaoli,paitsinimensämukaisestitoimiaväylänälakkautetustaEmestinteh taastasïrtyneentuotantopäälikönjavalmistuksenhenkilöstöntutustumiselle, ennenkaikkeakehittääavointa keskusteluajahodayhteisensunnnittehnkulthuria. Palaveritolivatperiaatteessaavoinnakaikilletyöntekijöille.Kätünnössäniihinosallistuiainoastaanyhdestä kahteen,yleensäsamaa, echustajaajokaosastolta $k o-$ koonpano, koneistusjapintakäsittely).Palavereissakäsiteltiinvvïkonaikanatehtyjätöitö, asiakkailtatulleita reklamaatioitajasumnnitellïnseuraavanviikontuotantoa
Kaikkialkanatosallistuavïkkopalavereihin. Toisin kuinkuukausipalovereitatyöntekïöidenenemmistöei nähnytTUTU-taiviikkopalavereitakovinkaantarpeellisiksi. Nütäkutsuttiïnvähätellen "toppatuolikeikoiksi" elineolivatvaintilaisuuksia,joihinmentiin istumaanpehmeilletuoleillejuttelemaanmukavia. Vïkkopalavereissakokoonpanoaedustavienhenkilöidenkannaltatilannediongelmallinen.Keskustehissanousiesün, ettähenäkivätasioidenyhteisenkäsittelyntärkeäksi, muttakokivatsamallahuonoaomaatuntoaosallistumisestapalavereihin

Kehittämisprojektinkäynnistämisenyhteydessätuotantopäällikkökertoitutkijoillemuidenasioidenlomassa myösaloittamistaanvïkkopalovereistajakysyiehdotuksianiidenkehittämiseksi. Tutkijatsuosittelivatjatkamaanvï̈kkopalaverikä̈täntöä,jajosmahdollista, ottamaankaikkityöntekijätmukaanpalovereihin.Viik- 
kopaloveri-kätäntömmutthikinsittenelokunssa,minkä jälkeennühinosallistuivatkaikkikokoonpanontyöntekïätjatuotantopäällikkö.Samallamautettïnpalavereidenpitopaikka: nï̈äeienääpidettytulosyksikköviidentyönjohtokopissa, vaankokoonpanonlattialla.

\section{Yhteenvetäviä kommentteja}

Tässä artikkelissa esitellyn kertovan muutosselonteon menetelmän avulla pystyttiin tuottamaan ajallisesti suhteellisen pitkäkestoista organisaatiomuutosta (lähes kolme vuotta) kuvaava narratiivi. Kyseessä ei ole kuitenkaan valmis metodi, vaan pikemminkin ensimmäinen kokeilu tai keskustelunavaus, joka nostanee esiin ainakin kahden tyyppisiä kysymyksiä (Ceglowski 1997): 1) kysymyksiä, jotka liittyvät kerronnallisten ratkaisujen tieteelliseen hyödyllisyyteen ja hyväksyttävyyteen sekä

2) kysymyksiä siitä, millä tavalla näitä tutkimuksia tulisi arvioida.

Lyhyiden kertomusten käyttöä käsitelleen artikkelinsa johtopäätöksissä Ceglowski (1997) toteaa, että vaikeinta ei ollut tutkimuksen kirjoittaminen, vaan sovelletun tutkimusotteen hyödyllisyyden osoittaminen. Tieteellisen hyväksyttävyyden osalta hän viittasi Richardsoniin (1996) joka oli todennut, että kertomuksellisia ratkaisuja soveltavat tutkijat nähdään usein pikemminkin hyvinä kirjoittajina kuin vakavasti otettavina tieteentekijöinä. Kertovan muutosselonteon menetelmässä on yritetty soveltaa aineksia erilaisista lähestymistavoista ja konstruoida jotain, joka olisi enemmän kuin mikään niistä yksinään. Tässä vaiheessa on vielä vaikea arvioida, kuinka hyvin tässä on onnistuttu. Menetelmää voidaan syyttää eklektisyydestä ja kysyä, mitä tieteellisesti hyödyllistä, ja uutta menetelmä tuo verrattuna esimerkiksi oraalihistorian tai etnografian metodeihin.

Metodologiseen näkökulmaan liittyen keskeinen kysymys on, kuinka arvioida kertomuksellisia tutkimuksia. Denison (1996) on ehdottanut, että tutkijan tulisi yhdessä tutkittavien kanssa varmistaa, että kertomukset kuvaavat tutkittujen kokemuksia. Kertovan muutosselonteon menetelmässä sovellettu neuvottelu-menettelytapa korostaa tutkijan ja tutkittavien tasa-arvoa ja on ehkä tavanomaista tutkimushenkilöillä hyväksyttämistä tehokkaampi tapa varmistaa tuotetun kertomuksen autenttisuus.

Denison (1996) ehdottaa myös, että metodologisen keskustelun pitäisi ottaa enemmän vaikutteita taiteiden ja kirjallisuuden tutkimuksen alueilta. Kertovan muutosselonteon menetelmässä vaikutteita otettiin elokuvan alueelta. Tosin elokuvan kerronnallisia ratkaisuja sovellettiin hyvin varoen ja tässä artikkelissa esitetty kuvaustapa perustui vielä täysin tapahtumien kronologiselle esittämiselle. Elokuvakerronnallisina keinoina kuvauksen parantamiseen voisivat olla esimerkiksi paralleelisen kuvaustekniikan käyttö ja kerronnalliset zoomaukset tärkeinä pidettyihin tapahtumiin (esimerkiksii Arijon 1976). Rinnakkaista kerrontaa voitaisiin käyttää esimerkiksi tilanteissa, joissa useat toimijat samanaikaisesti tekevät jotain samaan asiaan liittyvää. Tarkennukset taas voisivat kohdistua tärkeisiin käännekohtiin ja muihin kehittämisen avainepisodeihin.

Artikkeli perustuu Työsuojelurahaston tuella tehtyyn väitöskirjatutkimukseen Interventio ja muutos kokoonpanotyössä (Laitinen 1998). Tutkimuksen tekoon sen eri vaiheissa ovat myötävaikuttaneet jo aiemmin mainitun professori Kari. E. Nurmen lisäksi mm. professori Seppo Kontiainen, FT Matleena Pankakoski, DI Anneli Pulkkis, dosentti Urpo Sarala, FM Juhani Sulander, professori Veikko Teikari ja professori Matti Vartiainen. 


\section{Lähteet}

ARIJON, D. (1976) Grammar of the Film Language. London/Boston: Focal Press.

CWGLOWSKI, D. (1997) That's a Good Story, But Is It Really Research? Qualitative Inquiry 2, 188-201.

CZARNIEWSKA, B. (1998) A Narrative Approach to Organization Studies. Qualitative Research Meth-ods. Volume 43. California: Sage.

CZARNIEWSKA-JOERGES, B. (1995) Narration or Science? Collapsing the Division in Organization Studies. Organization 1, 11-33.

DENISON, J. (1996) Sports Narratives. Qualitative Inguiry 3, 351-362.

ERÄSAARI, L. (1995) Kohtaamisia byrokraattisilla näyttämöillä. Helsinki: Gaudeamus.

GUSTAVSEN, B., Hart, H. ja Hofmaier, B. (1991) From Linear to Interactive Logics: Characteristics of Workplace Development as Illustrated by Projects in Large Mail Centers. Human Relations 4, 309-332.

GUSTAVSEN, B., Hofmaier, B., Ekman Philips, M. ja Wikman, A. (1996) Concept-Driven Development and the Organization of the Process of Change. Stockholm: The National Institute for Working Life.

FORSSÉN-NYBERG, M. (1995) Toimistossa tapahtuu toimistotyön osallistuva tutkimus- ja kehittämishanke. Teknillinen korkeakoulu, Teollisuustalous ja Työpsykologia. Raportti 161 .

HAKANEN, J. (1991) Kuoleman kolme näyttämöä: etogeeninen tarkastelu. Helsingin yliopiston sosiaalipsykologian laitoksen tutkimuksia 1/1991.

HAMMERSLEY, M. (1992) What's Wrong with Ethnography? London: Routledge.

HARRÉ, R. (1979) Social Being. A Theory for Social Psychology. Oxford: Basil Blackwell.

HARRÉ, R. (1974) Blueprint for a New Science. Teoksessa Armistead, N. (Toim.) Reconstructuring Social Psychology. Norfolk: Penguin.

HARRÉ, R., Clarke, D. ja De Carlo, N. (1985) Motives and Mechanisms. An Introduction to the Psychology of Action. London: Methuen.

HARRE, R. ja Gillett, G. (1994) The Discursive Mind. Thousand Oaks: SAGE.

HARRÉ, R. ja Secord P. (1972) The Explanation of Social Behaviour. Oxford: Basil Blackwell.

HARRÉ, R. ja Secord P. (1972) The Explanation of Social Behaviour. Oxford: Basil Blackwell.

HARRISON, R. (1995) Consultant's Journey. London: McGraw-Hill.

HEIKKINEN, R. (1989) Laadullisen neuvonta-aineiston valottama terveyskasvatusanalyysi. Tampereen yliopisto. Kasvatustieteen laitos. Julkaisusarja A. Tutkimusraportti 42/1990.

LAITINEN, M. (1998) Interventio ja muutos kokoonpanotyössä. Siirtyminen itseohjautuviin ryhmiin teollisuusyrityksessä. Helsingin yliopiston Kasvatustieteen laitoksen tutkimuksia 160.

MARRIS, P. (1974) Loss and Change. London: Routledge and Kegan Paul.

Marsh, P., Rosser, E. ja Harré, R. (1978) The Rules of Disorder. London: Routledge and Kegan Paul.

MISHLER, E. (1995) Models of Narrative Analysis: A Typology. Journal of Narrative and Life History 2, 87-123
MYLLYNIEMI, R. (1998) Etogenia. Teoksessa Helkama, K., Myllyniemi, R. ja Liebkind, K. Johdatus sosiaalipsykologiaan. Helsinki: Edita.

NOER, D. (1993) Healing the Wounds: Overcoming the Trauma on Layoffs and Revitalizing Downsized Organizations. San Francisco: Jossey Bass.

PRATT, M. (1986) Fieldwork in Common Places. Teoksessa Clifford, J. ja Marcus, G. (Toim.) Writing Culture: the Poetics and Politics of Ethnography. Berkeley: University of California Press.

RICHARDSON, L. (1996) Educational Birds. Journal of Contemporary Ethnography 1, 6-15.

SENGE, P. (1990) The Fifth Discipline: The Art and Practice of the Learning Organization. New York: Doupleday

Sulander, J. (1992) Oikeudenmukaisuus tuotantoryhmissä. Sosiaalipsykologian syventävien opintojen tutkielma. Helsingin yliopisto, Sosiaalipsykologian laitos.

THOMPSON, P. (1988) The Voice of the Past. Oral History. Oxford: Oxford University Press

THUKYDIDES (400 eKr.). Peloponnesolaissota. Hollo, J. suomentanut 1964. Porvoo: WSOY.

TOSEY, P. and Nicholls, G. (1999) Ofsted and Organizational Learning: the Incidental Value of the Dunce's Cap as a Strategy for School Improvement. Käsikirjoitus.

UOTILA, K. ja Ylijoki, O. (1984) Etogenia. Harrén ja Secordin lähestymistapa vuorovaikutustutkimukseen. Psykologia 2, 89-93

VALKONEN, J. (1997) Tarinallisuus kuntoutuksessa. Psykologia 6, 415-426

YOW, V. (1994) Recording Oral History. California: SAGE.

\section{Viitteet}

1 Tässä esiteltävä menetelmä on kehitetty yhteistyössä prof. Kari, E. Nurmen kanssa ja on perusteellisemmin kuvattu julkaisussa Interventio ja muutos kokoonpanotyössä (Laitinen 1998).

2 Vertaa esimerkiksi historian tutkimuksen isänä pidetyn Thukydideen (noin $400 \mathrm{eKr}$.) luomaan historiantutkimuksen metodiin

Artikkeli saapui toimitukseen 21.4.1999. Se hyväksyttiin julkaistavaksi 7.6.1999. 